\title{
Active learning method for health life implementation in new normal era in Tanjung Sari Medan
}

\author{
Tri Widyawati ${ }^{1 *}$, Siti Syarifah ${ }^{1}$, Yunita Sari Pane ${ }^{1}$, Milahayati Daulay $^{2}$, Dwi Rita Anggraini ${ }^{3}$ \\ ${ }^{1}$ Department of Pharmacology and Therapeutic, Faculty of Medicine, Universitas Sumatera \\ Utara, Medan,Indonesia \\ ${ }^{2}$ Department of Physiology, Faculty of Medicine, Universitas Sumatera Utara, Medan,Indonesia \\ ${ }^{3}$ Department of Anatomy, Faculty of Medicine, Universitas Sumatera Utara, Medan, Indonesia \\ *Email: tw_rozan@yahoo.com
}

\begin{abstract}
COVID-19 or Corona Virus Disease 2019 is a virus which has been endemic in 2020 worldwide and has been declared a pandemic by WHO. The spread of virus is fast sharply with an increase in cases every day, including in Medan City. Ten of the sub-districts are destined as the red zone, including Tanjung Sari Village, which is located in Medan Selayang District. The lack of health promotion related to the appropiate use of drugs and changes to a hygienic lifestyle need education in facing the life of the new normal era nowadays. Therefore, community service activities related to education using the Instant Active Learning / Cara Belajar Insan Aktif (CBIA) method need to be carried out to prevent and to deal with the spread of COVID-19. This activity was carried out by providing education materials both in the form of powerpoint and videos to twenty housewives in Tanjung Sari village. The participants were evaluated before and after the program by giving questionnaire to asses their knowledge and uderstanding. The contents of education including the COVID-19 spread prevention way, selfprotection tools, general knowledge to use medicines correctly and a hygienic lifestyle. The materials were delivered by the CBIA method. Data from evaluation were analysed by T-dependent test, $\mathrm{p}<0.05$ was considered significant. The results showed that the characteristics of the participants as follows: 9 participants aged 21-30 years (45\%), 17 people worked as housewives (85\%), as many as 12 people having high school or vocational education level $(60 \%)$. There was a significant effect on the provision of education on participants' knowledge $(\mathrm{p}<0.05)$. This program gained participants knowledge and understanding on prevention way of COVID-19, the correct use of medicines and hygienic lifestyle.
\end{abstract}

Keyword: COVID-19, Instant active learning, protection tools

\begin{abstract}
Abstrak
COVID-19 atau Corona Virus Disease 2019 merupakan virus yang mewabah pada tahun 2020 keseluruh dunia dan telah ditetapkan sebagai pandemi oleh WHO. Penyebaran yang sangat mudah dan meluas tajam dengan peningkatan kasus setiap harinya, termasuk di Kota Medan. 10 kecamatan diantaranya ditetapkan sebagai zona merah termasuk kelurahan Tanjung Sari yang terletak di Kecamatan Medan Selayang. Minimnya promosi kesehatan terkait penggunaan obat yang benar dan perubahan pola hidup higienis memerlukan edukasi dalam menghadapi era new normal saat ini. Oleh karena itu, kegiatan pengabdian masyarakat terkait edukasi dengan metode cara Belajar Instant Aktif (CBIA) ini perlu dilakukan untuk mencegah penyebaran COVID-19. Kegiatan dilaksanakan dengan pemberian materi dalam bentuk presentasi powerpoint dan video pembelajaran kepada 20 orang ibu rumah tangga di kelurahan Tanjung Sari. Peserta dievaluasi sebelum dan sesudah kegiatan melalui kuesioner untuk menilai perubahan pengetahuan mereka. Materi yang disampaikan terdiri dari cara pencegahan penyebaran COVID-19, alat perlindungan diri, pengetahuan umum tentang penggunaan obat yang benar serta pola hidup higienis. Materia disampaikan dengan metode CBIA. Data yang diperoleh dianalisis dengan uji T-dependent, $\mathrm{p}<0,05$ dianggap bermakna. Hasilnya menunjukkan karakteristik peserta: usia 21-30 tahun sebanyak 9 orang (45\%); 17 orang bekerja sebagai ibu rumah tangga (85\%); 12 orang memiliki tingkat pendidikan SMA/SMK (60\%). Terdapat perbedaan pengetahuan yang bermakna sebelum dan sesudah pemberian materi $(\mathrm{p}<0,05)$. Kegiatan ini meningkatkan pengetahuan dan pemahaman peserta tentang COVID-19, penggunaan obat yang benar serta pola hidup higienis.
\end{abstract}

Kata Kunci: COVID-19, Cara Belajar Insan Aktif, alat perlindungan diri 


\section{PENDAhuluan}

Corona Virus Disease 2019 (COVID-19) adalah infeksi yang disebabkan oleh virus SarsCoV- 2 yang dapat menyebabkan gangguan sistem pernapasan yang bersifat akut dan gagal ginjal. Penyebaran COVID-19 yang telah ditetapkan sebagai pandemik global oleh World Health Organization (WHO) pada tanggal 11 Maret 2020 semakin meluas dengan tajamnya peningkatan jumlah kasus setiap harinya (Kemenkes, 2020).

Kelurahan Tanjung Sari merupakan salah satu kelurahan yang ada di kecamatan Medan Selayang yang berlokasi di Jalan Setia Budi Pasar 1 Medan, Sumatera Utara. Kelurahan ini dapat diakses dengan berbagai sarana transportasi termasuk angkutan umum. Kelurahan ini merupakan kelurahan dengan cakupan masyarakat cukup banyak dan perumahan yang cukup padat yang memiliki 18 kepala lingkungan. Hal ini memiliki potensi yang besar dalam penyebaran virus COVID-19 kepada masyarakat. Kelurahan Tanjung Sari juga merupakan kelurahan yang termasuk dalam zona merah penyebaran COVID-19.

Saat ini, dengan telah ditetapkannya istilah new normal oleh pemerintah sebagai upaya untuk mempercepat penanganan COVID-19 dalam aspek kesehatan dan sosial-ekonomi, maka perlu dilakukan edukasi kepada masyarakat mengenai implementasinya dalam mencegah penyebaran COVID-19. Upaya yang dapat dilakukan adalah dengan menerapkan lingkungan yang bersih dan higienis, melalui cuci tangan dengan sabun, menggunakan hand sanitizer dan desinfektan. Upaya lain yang dapat dilakukan adalah melalui promosi kesehatan terkait penggunaan obat yang baik dan benar. Hal ini dilakukan agar masyarakat berhati-hati dalam pengunaan obat selama kondisi new normal dalam menghadapi pandemik ini, terutama pada masyarakat di Kelurahan Tanjung Sari. Sebagaimana diskusi yang telah dilakukan dengan kepala lingkungan IX, diketahui bahwa promosi kesehatan terkait pencegahan COVID-19, penggunaan obat-obatan yang baik dan benar serta penerapan pola hidup bersih dan higienis belum pernah dilakukan di lingkungan ini.

Berdasarkan paparan diatas, tim pengusul mengadakan kegiatan edukasi melalui Cara Belajar Insan Aktif (CBIA) tentang pencegahan penyebaran COVID-19, penggunaan obat-obatan yang baik dan benar serta penerapan pola hidup bersih dan higienis. Melalui kegiatan ini diharapkan dapat meningkatkan pengetahuan dan pemahaman peserta serta dapat menjadi perwakilan untuk meneruskan informasi yang diperoleh dengan baik dan benar di lingkungannya. Pada kegiatan pengabdian ini, tim juga menganalisis data untuk mengetahui karakteristik umum dan mengevaluasi ada tidaknya perubahan pengetahuan peserta sebelum dan sesudah penyajian materi.

\section{METODE PELAKSANAAN}

Kegiatan pengabdian masyarakat ini dilaksanakan oleh tim Pengabdian Masyarakat pada bulan November tahun 2020 yang terdiri dari dosen Fakultas Kedokteran Universitas Sumatera Utara kepada golongan ibu rumah tangga di kelurahan Tanjung Sari, Medan. Kegiatan dilakukan dalam bentuk pelatihan dengan metode CBIA secara bertahap untuk tiap golongan peserta. Secara teknis tiap pertemuan peserta dibagi menjadi 2 kelompok terdiri dari 10 orang ibu rumah tangga.

Pelaksanaan kegiatan ini dilakukan sesuai dengan tahapan dibawah ini, yakni:

1. Pengisian kuesioner (soal pre-test) oleh seluruh peserta

2. Pemutaran video edukasi-1 tentang penggolongan obat modern dan obat tradisional dan diskusi secara CBIA

3. Presentasi dan Diskusi tentang Upaya Pencegahan Penyebaran Covid

4. Pemutaran Video Cara Pembuatan Hand Sanitizer dan Desinfektan, dilanjutkan dengan praktek

5. Pengisian kuesioner (soal post-test) oleh seluruh peserta

Metode Cara Belajar Insan Aktif (CBIA)

Pada penerapan Metode CBIA, langkah-langkah yang dilakukan adalah sebagai berikut: 
Tri Widyawati et al. Active learning method for health life implementation

1. Setiap kelompok (10 orang dibagi kedalam 3 kelompok kecil) dibagikan paket obat tertentu yang telah disiapkan

2. Peserta diminta untuk mengelompokkan dan mendiskusikan obat berdasarkan golongan yang telah dipelajarinya melalui video.

3. Perwakilan setiap kelompok kecil mempresentasikan secara bergantian terkait hasil diskusi

4. Setiap peserta boleh memberikan respon dan pertanyaan terhadap presentator

Pada kegiatan pengabdian ini, pengusul juga mengumpulkan data karakteristik peserta meliputi usia, pekerjaan, tingkat pendidikan. Data hasil kuesioner (soal pre-test dan post-test) dianalisa secara statistik dengan menggunakan uji T-dependent untuk mengetahui apakah terdapat pengaruh pemberian edukasi dengan metode CBIA terhadap pengetahuan peserta.

\section{HASIL DAN PEMBAHASAN (RESULT AND DISCUSSION)}

Ketua Tim Pengabdian USU dan tim melaksanakan seluruh rangkaian kegiatan yang diawali dengan pre-test (Gambar 3.1). Sebanyak 20 orang peserta dibagi menjadi 2 kelompok yakni kelompok 1 dan kelompok 2. Pengambilan data pada kelompok 1 dan 2 dilakukan pada hari yang berbeda dengan tujuan untuk menerapkan protokol kesehatan yang baik. Setiap kelompok terdiri atas 10 orang. Para peserta ditempatkan pada posisi dengan jarak 1-2 meter sebelum diinstruksikan untuk mengisi soal pre-test. Pre-test terdiri dari 15 soal yang mencakup pengetahuan tentang alat pelindung diri (APD) (5 soal), pengetahuan tentang penggolongan obat ( 8 soal) dan pola hidup bersih dan higienis ( 2 soal). Peserta tidak diperkenankan untuk mencari informasi dengan bertanya pada teman atau melihat di telepon genggam.

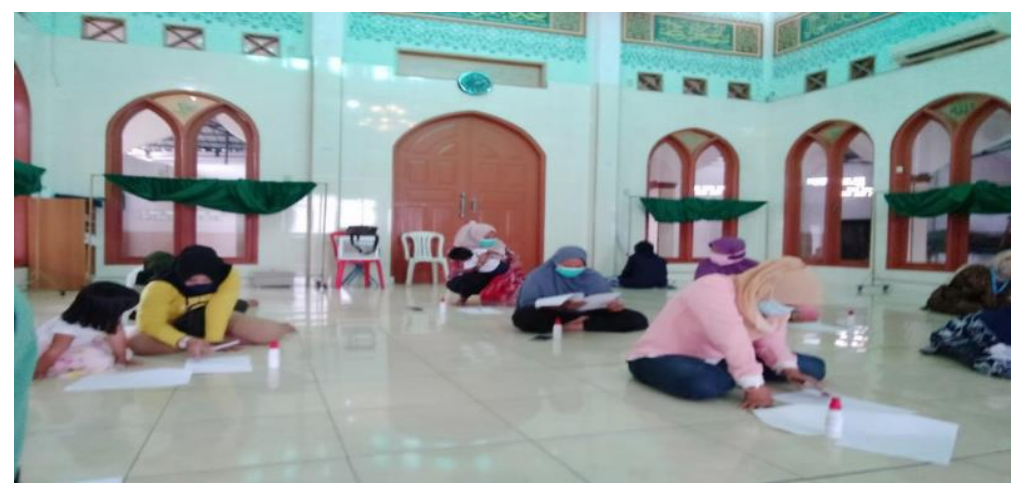

Gambar 3.1. Kegiatan pengisian soal pre-test pada kelompok 1

Kegiatan pemutaran video edukasi dilakukan setelah peserta selesai mengerjakan soal pre-tes. Materi dalam video pembelajaran berisi tentang penggolongan obat modern dan obat tradisional. Sebelum menyaksikan video, peserta terlebih dahulu diberikan leaflet berisi ringkasan materi untuk mempermudah pemahaman mereka terhadap materi yang disajikan. Selanjutnya kegiatan diskusi dilakukan setelah pemutaran video selesai. 


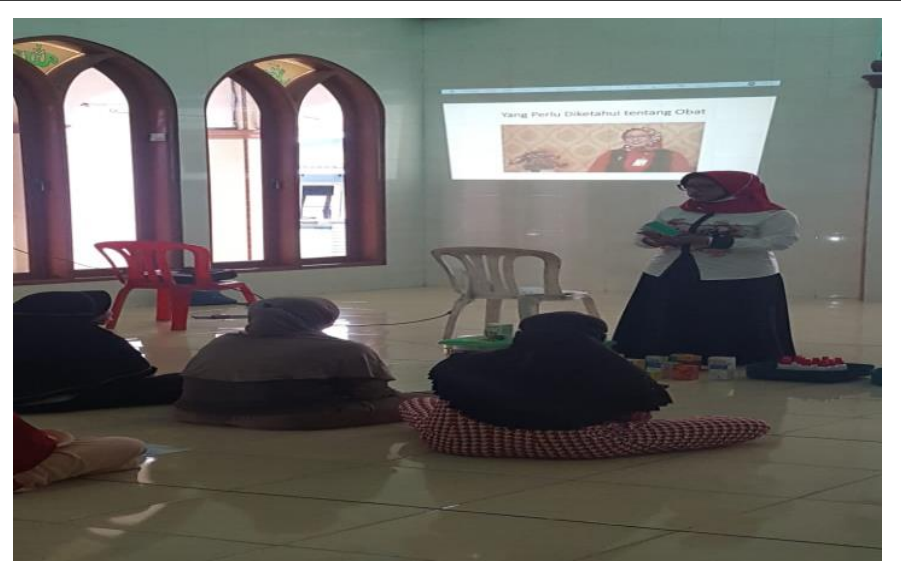

Gambar 3.2 Pemutaran video tentang penggolongan obat

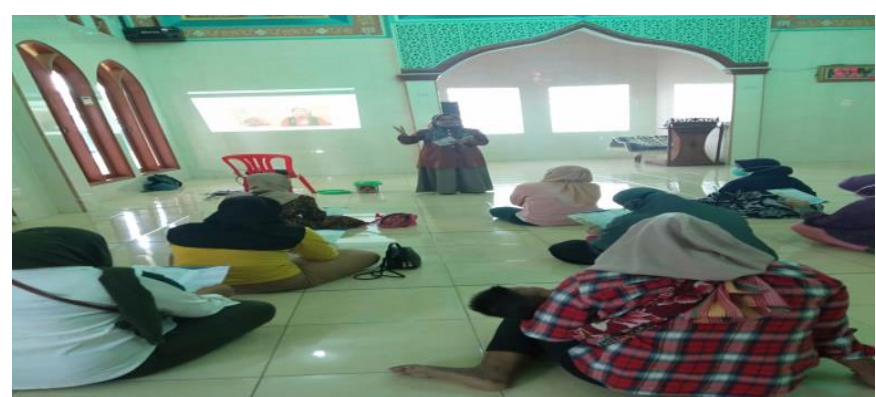

Gambar 3.3 Kegiatan diskusi secara CBIA kelompok 2

Kegiatan presentasi dan diskusi terkait COVID-19 dilakukan setelah diskusi terkait penggolongan obat usai. Selanjutnya penyampaian materi tentang hand sanitizer dan desinfektan. Pada sesi ini, peserta diberikan informasi mengenai pembuatan hand sanitizer sesuai standar WHO sebanyak $1 \mathrm{~L}$ secara mandiri dengan prosedur sebagai berikut:

Bahan yang diperlukan: etanol 96\%, hydrogen peroksida 3\%, gliserol 98\%, akuades.

Alat : gelas ukur $(50 \mathrm{ml}, 100 \mathrm{ml}, 1000 \mathrm{ml})$, corong kaca, batang pengaduk. botol kemasan.

Prosedur:

1. Sejumlah $833 \mathrm{ml}$ etanol $96 \%$ dimasukkan ke dalam gelas ukur $1000 \mathrm{ml}$

2. Ditambahkan $41,7 \mathrm{ml}$ hidrogen peroksida $3 \%$ ke dalam gelas ukur berisi etanol tersebut

3. Sebanyak $14,5 \mathrm{ml}$ gliserol $98 \%$ dimasukkan ke campuran no 2. menggunakan gelas ukur

4. Ditambah akuades hingga $1000 \mathrm{ml}$, kemudian diaduk hingga homogen.

5. Masukkan dalam wadah botol spray (Gambar 3.4).

Selain diberikan informasi terkait komposisi pembuatan hand sanitizer secara mandiri, peserta juga diberikan informasi cara pembuatan desinfektan secara mandiri. Adapun cara membuatnya bisa dengan salah satu bahan dasar pembersih lantai (®Wipol) atau pemutih pakaian (®Bayclin). Adapun tahap pembuatannya sebagai berikut:

A. Desinfektan dengan kadar Pine oil 0,23\% dari Wipol (Pine oil 2,5\%).

Diambil cairan Wipol sebanyak $90 \mathrm{ml}$, kemudian ditambah air sebanyak $910 \mathrm{ml}$ untuk menghasilkan cairan desinfektan sebanyak $1000 \mathrm{ml}$ atau $1 \mathrm{~L}$.

B. Desinfektan dengan kadar $\mathrm{NaOCl} 0,1 \%$ dari Bayclin $(\mathrm{NaOCl} 5,25 \%)$.

Diambil cairan Bayclin sebanyak $20 \mathrm{ml}$, kemudian ditambah air sebanyak $980 \mathrm{ml}$ untuk menghasilkan caitan desinfektan sebanyak $1 \mathrm{~L}$. 


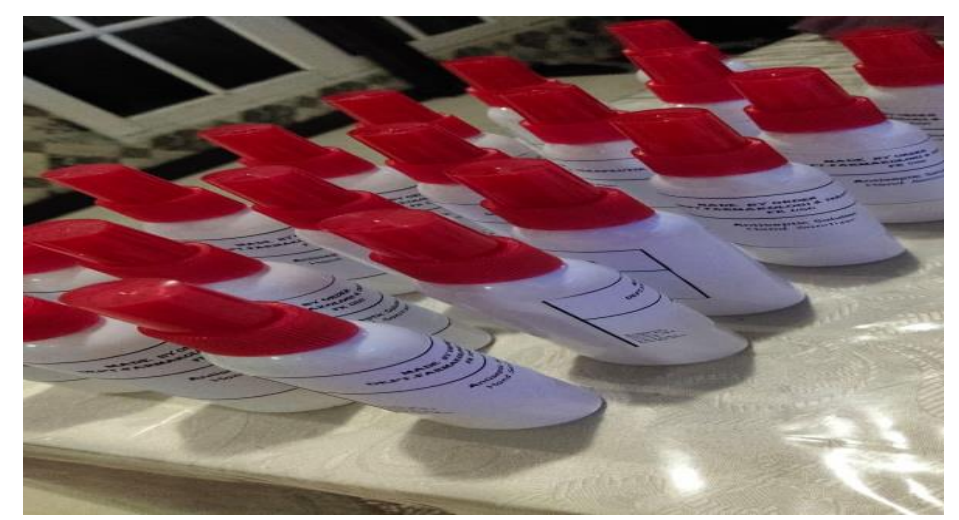

Gambar 3.4 Hasil praktek pembuatan hand sanitizer dalam kemasan botol spray

Pada kegiatan pengabdian masyarakat ini, tim mengambil beberapa data terkait karakteristik peserta. Data karakteristik peserta dapat dilihat pada tabel 4.1 dibawah ini:

Tabel 4.1 Karakteristik peserta berdasarkan usia

\begin{tabular}{ccc}
\hline \multirow{2}{*}{$\begin{array}{c}\text { Rentang usia } \\
\text { (tahun) }\end{array}$} & Frekuensi \\
\cline { 2 - 3 } & $\mathbf{n}$ & \% \\
\hline $10-20$ & 2 & 10 \\
$21-30$ & 9 & 45 \\
$31-40$ & 4 & 20 \\
$41-50$ & 1 & 5 \\
$51-60$ & 3 & 15 \\
$61-70$ & 1 & 5 \\
\hline
\end{tabular}

Berdasarkan tabel 4.1 diatas, dapat dilihat bahwa mayoritas peserta berada pada rentang usia 21-30 tahun yakni sebanyak 9 orang $(45 \%)$ sedangkan peserta termuda adalah wanita berumur 17 tahun sebanyak 2 orang (10\%) dan peserta tertua adalah wanita berumur 61 tahun sebanyak 1 orang (5\%).

Selanjutnya karakteristik peserta berdasarkan pekerjaan dapat dilihat pada tabel 4.2.

Tabel 4.2 Karakteristik peserta berdasarkan pekerjaan

\begin{tabular}{lcc}
\hline \multirow{2}{*}{ Pekerjaan } & \multicolumn{2}{c}{ Frekuensi } \\
\cline { 2 - 3 } Ibu Rumah Tangga & $\mathbf{n}$ & \% \\
Peg.Negeri Sipil (PNS) & 17 & 85 \\
Kader Posyandu & 1 & 5 \\
Guru TK & 1 & 5 \\
\hline
\end{tabular}


Tri Widyawati et al. Active learning method for health life implementation

Berdasarkan tabel 4.2 diatas, dapat dilihat bahwa mayoritas peserta adalah ibu rumah tangga yaitu sebanyak 17 orang $(85 \%)$ dan 3 orang lainnya selain sebagai ibu rumah tangga juga bekerja sebagai PNS, kader posyandu dan guru TK.

Tabel 4.3 Karakteristik pekerja berdasarkan pendidikan

\begin{tabular}{lcc}
\hline & \multicolumn{2}{c}{ Frekuensi } \\
\cline { 2 - 3 } \multicolumn{1}{c}{ Tingkat pendidikan } & $\mathbf{n}$ & \% \\
SD & 5 & 25 \\
SMP & 1 & 5 \\
SMA & 6 & 30 \\
SMK & 6 & 30 \\
S1 & 2 & 10 \\
\hline
\end{tabular}

Berdasarkan tabel 4.3 diatas, dapat dilihat bahwa mayoritas peserta memiliki tingkat pendidikan SMA/Sederajat (SMA-SMK) yakni sebanyak 12 orang (60\%), namun masih ada juga 5 orang (25\%) yang memiliki tingkat pendidikan SD dan hanya 2 orang (10\%) yang memiliki tingkat pendidikan Sarjana (S1).

Pada analisa statistik, kami melakukan uji normalitas data terlebih dahulu dan data didapatkan terdistribusi normal ( untuk data nilai soal pre-test dan post-test). Uji statistik yang digunakan adalah uji T-dependent untuk menilai perbedaan antara nilai sebelum (pre-test) dan nilai sesudah (post-test) sesudah peserta diberikan materi. Hasil uji statistik disajikan pada tabel 4.4.

Tabel 4.4 Perbedaan skor nilai sebelum dan sesudah pemberian materi

\begin{tabular}{ccc}
\hline Nilai & Rerata \pm SB & $\boldsymbol{p}$ \\
\hline Pre-test & $51,69 \pm 18,09$ & $0,003^{*}$ \\
Post-test & $68,70 \pm 18,50$ & \\
\hline
\end{tabular}

Berdasarkan tabel 4.4. diatas, dapat dilihat bahwa nilai $\mathrm{p}<0,05$ yang menunjukkan terdapat perbedaan bermakna skor nilai yang diperoleh peserta sebelum dan sesudah pemberian materi edukasi. Data diatas menunjukkan bahwa terdapat pengaruh pemberian materi edukasi terhadap pengetahuan peserta terkait COVID-19, penggunaan obat yang baik dan pola hidup bersih dan higienis.

Pemberian cinderamata pada peserta dilakukan setelah seluruh rangkaian kegiatan dilakukan. Peserta dibekali dengan satu botol hand sanitizer yang telah dibuat secara mandiri dan satu botol pemutih pakaian merk Bayclin. Pemberian satu botol pemutih pakaian dilakukan agar peserta dapat membuatnya sendiri di rumah sebagai desinfektan sesuai dengan langkahlangkah yang telah dijelaskan selama pemberian materi. Peserta juga diberikan leaflet yang berisi informasi tentang COVID-19, APD, penggolongan obat dan pembuatan hand sanitizer dan desinfektan secara mandiri (Gambar 3.5-3.6). Pemberian leaflet dilakukan agar peserta 
dapat meneruskan informasi kepada lingkungan sekitarnya sebagai perwakilan tim pengabdian masyarakat USU di masyarakat untuk penyampaian informasi yang lebih luas.

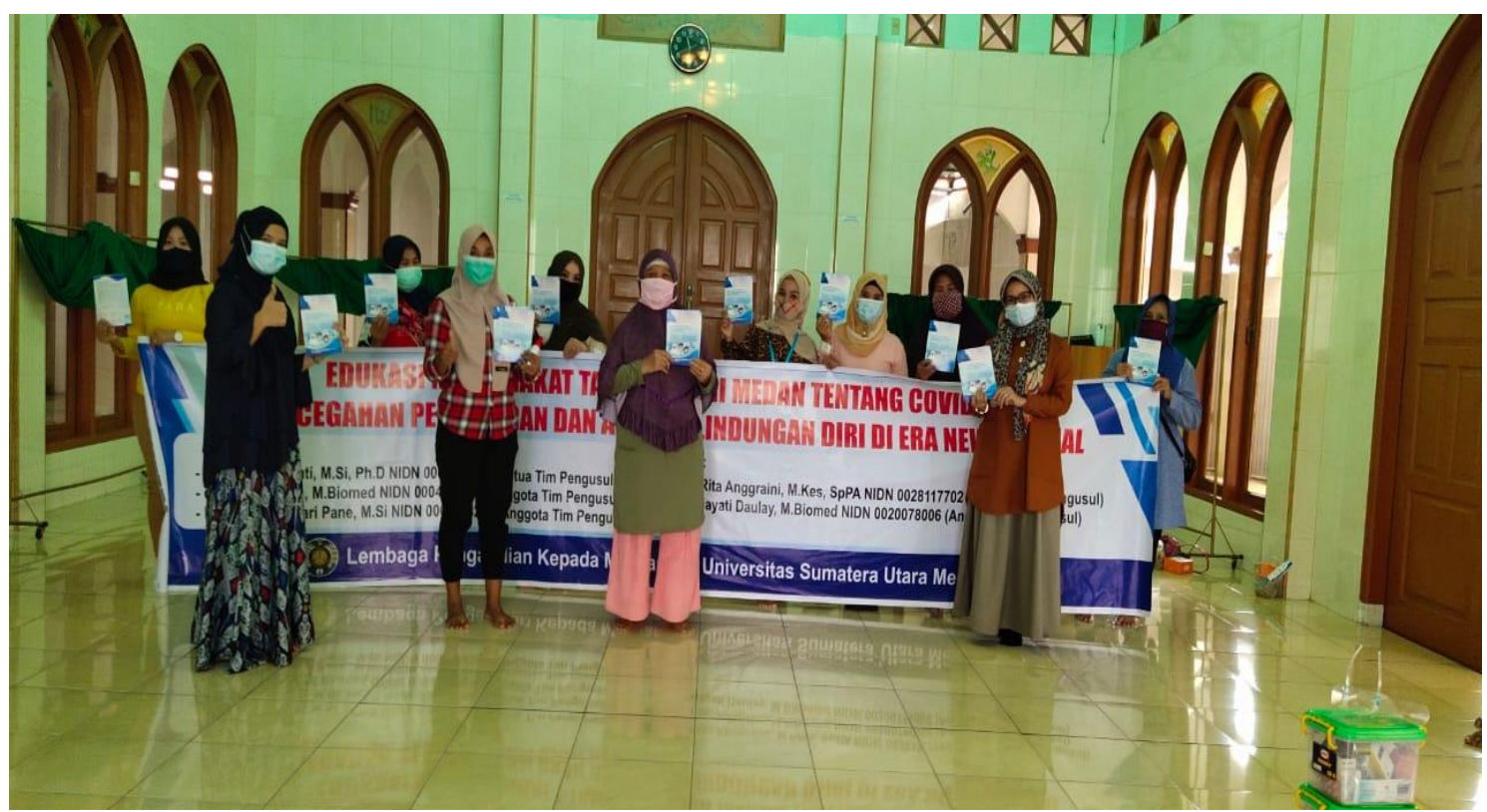

Gambar 3.5 Pemberian leafleat pada peserta kelompok 1

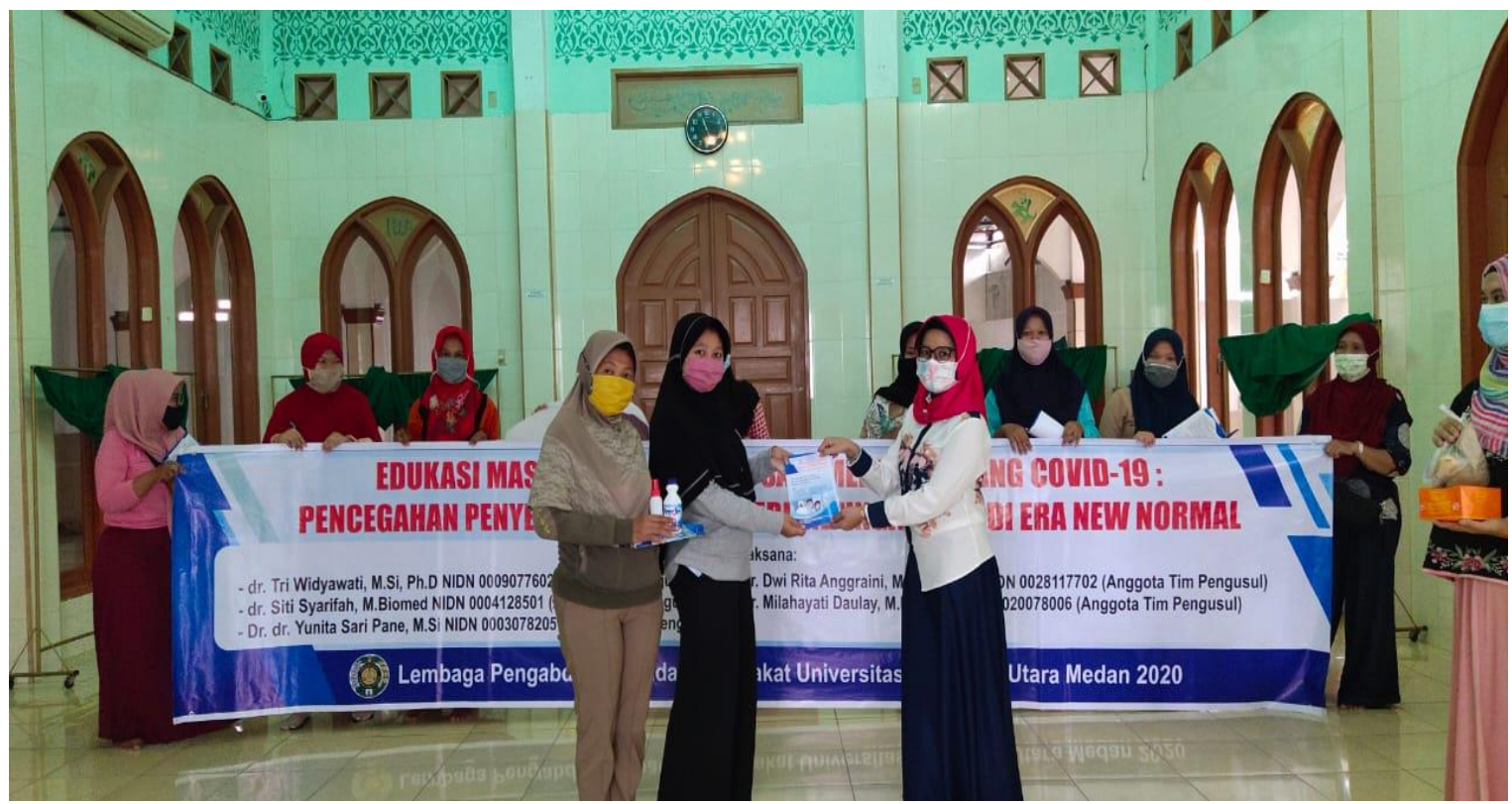

Gambar 3.6 Pemberian hand sanitizer dan leaflet pada perwakilan peserta kelompok 2

\section{KESIMPULAN}

Peserta mendapatkan pengetahuan tentang pencegahan penyebaran COVID-19, penggunaan alat pelindung diri, penggunaan obat yang benar serta pola hidup bersih dan higienis. Karakteristik peserta dengan rentang usia 21-30 tahun sebanyak 9 orang (45\%), sebanyak 17 orang bekerja sebagai ibu rumah tangga (85\%), sebanyak 12 orang memiliki tingkat pendidikan SMA/SMK (60\%). Dijumpai perubahan 
pengetahuan yang bermakna terhadap materi yang disajikan. Kegiatan pengabdian masyarakat berupa pemberian edukasi (materi dan video) dengan metode CBIA dapat digunakan untuk meningkatkan pengetahuan dan pemahaman peserta tentang pencegahan penyebaran COVID-19, penggunaan obat yang benar serta pola hidup bersih.

\section{UCAPAN TERIMAKASIH}

Kegiatan ini merupakan luaran dari dari Program Pengabdian kepada Masyarakat skema Dosen Mengabdi yang dibiayai oleh dana NON PNBP Universitas Sumatera Utara dengan nomor: 754/UN5.2.3.2.1/PPM/2020. Terima kasih juga kepada mitra pada kegiatan pengabdian ini, Kepala Lingkungan IX Kelurahan Tanjung Sari Medan.

\section{DAFTAR PUSTAKA}

Edwards,I.R., Aronson J.K. (2000). Adverse drug reactions: Definitions, Diagnosis, and Management. The Lancet, 356(9237), 1255-1259.

Gusnelyanti. 2014. Mencerdaskan masyarakat dalam penggunaan obat melalui metode Cara Belajar Insan Aktif (CBIA). Diunduh di http://binfar.kemkes.go.id

Suryawati, S. (2012). Meningkatkan keterampilan memilih obat dengan metode CBIA. Pusat Studi Farmakologi Klinik dan Kebijakan Obat UGM. Yogyakarta.

Tim ICT Dinas Kominfo Kota Medan. Puskesmas Glugur Darat. 2016. Diunduh dari http://pemkomedan.go.id/new/puskesmas-glugur-darat.html\#ixzz3x33SMckS

Katzung B.G.,Trevor A.J. (2004). Basic \& clinical pharmacology (Vol. 8). New York: Lange Medical Books/McGraw-Hill. 